\title{
No effects of drought on the most abundant small Passerine birds in Wetlands of semiarid landscapes
}

\begin{abstract}
One of the most important direct effects of climate change is the continuous increasing of droughts, particularly in arid and semiarid regions. By the use of temporal climatic datasets of fourteen years (1991-2004) and information arisen from ringing captures of small reed passerines it is demonstrated that drought cycles in a wetland of SE Spain, immerse in a semiarid landscape, had not effect on the two small passerines that conform the gross of the reed-bed bird's assemblage, in terms of abundance and biomass. Weak breeding seasons caused by drastic environmental events may have a synergic effect on the different flexibility of the moult strategies and morphological adaptations of well adapted individual body-sizes and hence not affecting them. Finally, novel studies focused on genomic sequence and environmental change in non-model species like birds could offer future prospects to find drought-resistant genes in small individual birds associated to terrestrial aquatic bodies in especially sensitive areas as the semiarid landscapes.
\end{abstract}

Volume 3 Issue 5 - 2018

Ignacio García Peiró

Department of Ecology \& Hydrology, University of Murcia, Spain

Correspondence: Ignacio García Peiró, Department of Ecology \& Hydrology, Faculty of Biology, University of Murcia, C/ El Salvador, 17-4D. 03023 Elche (Alicante), Spain, Phone (00) 34 965451 777, Fax (00) 965421320 ,

Email ignacio.peiro@yahoo.es

Received: July 31, 2018 | Published: September 12, 2018

Keywords: drougths, bird's assemblage, wetlands, semiarid regions, SE Spain

\section{Introduction}

Drought is a widespread event chiefly given in areas and regions submitted to a high temperatures and small rainfall as for example wetlands immerse in arid and semiarid landscapes. Climate change is involving considerable territories and likely limits further expansions of water bodies. ${ }^{1,2}$ In these sectors, wetlands and other wet spaces depend properly of hydrological regimes which are submitted to strong cyclic seasonality. This cyclic seasonality, altered by climate change, is influencing directly the full biodiversity of the fauna and flora of wetlands. ${ }^{3}$ Fluctuations in flood degrees can provide restrictions of frameworks that run its communities as diversity, eveness, specific turnover, etc ${ }^{4,5}$ or can provide contractions in the breeding success of birds but no its complete block. ${ }^{6}$

It has investigated, by means ringing programs, that two small Passerine birds explain the most bird's assemblage of Mediterranean wetlands in terms of biomass ${ }^{7}$ and quantity. ${ }^{8}$ One of them is a widespread breeder or afro-tropical migrant in Eurasia highly linked to reed-beds ${ }^{9}$ and the other is a principal breeder in mainland Eurasia but overwinter in Mediterranean regions using reed-beds as suboptimal habitat. ${ }^{10}$

\section{Material and methods}

To check the effect of droughts on the bird's quantity in a semiarid Mediterranean wetland (El Hondo Natural Park, SE Spain), I essentially recorded the drought cycles by means of the residuals on the linear regression of the year (1991-2004) on the overall annual rainfall $(\mathrm{mm})$. Afterwards I correlated both (Pearson's r) with the annual total number of ringed birds gathered for the period 1991-2004.

\section{Results}

The correlation among annual drought events by ringing totals didn't provide serious effects for the afro-tropical summer visitant Eurasian Reed Warbler (Acrocephalus scirpaceus) and the winter visitant Common Chiffchaff (Phylloscopus collybita) (Figure 1 and 2).

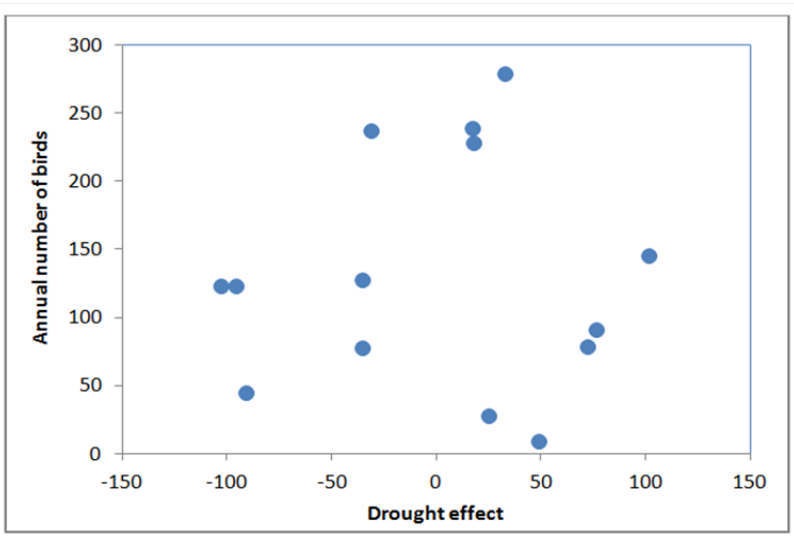

Figure I Weakly positive relation among drought effect (see Material and Methods) and number of Eurasian Reed Warblers (Acrocephalus scirpaceus). Pearson's correlation not significant $(r=0.04 ; P=0.703$, d. $f=14)$.

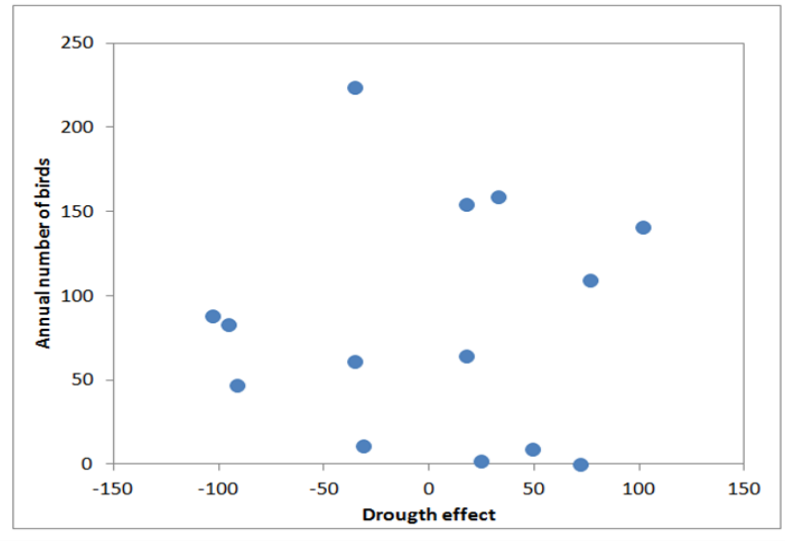

Figure 2 Weakly positive relation among drought effect (see Material and Methods) and number of Common Chiffchaffs (Phylloscopus collybita). Pearson's correlation not significant $(r=0.07 ; P=0.277$, d. $f=14)$. 


\section{Discussion}

This evaluation provides evidence that the gross of the small reedbed bird's assemblage in a man-made semiarid wetland, in terms of abundance and biomass ${ }^{7}$ does not depend on drought episodes, but may occur an effect the human-mediated management of waters ${ }^{11}$ not here analysed. Droughts may influence alternative units of the community structure such as richness and diversity ${ }^{12}$ involving the migratory strategy and the habitat selection of wetland passerines ${ }^{13,14}$ but not the magnitude of the bird's assemblage in quantitative terms. In fact, the effect of climate change, may not influence the population sizes of species in an ecosystem, because prevents the competitive exclusion of sympatric species and enhancing its abundances ${ }^{15-17}$ but it can shape the quality in terms of richness, by falling off the number of species. ${ }^{18,19}$ It has been proved that in arid climates, weak breeding seasons due to climatic conditions are linked to the different flexibility of moult strategies in species that coexist at various periods. Different moult strategies of Eurasian Reed Warblers and Chiffchaffs carried out at distant seasons ${ }^{20}$ might have a synergic effect induced by unsuccessful years due to harsh environmental conditions and thus have not effect on survival and the overall abundance. ${ }^{21}$ On the other hand, morphological adjustments of boy-size to high-temperatures in arid climates resulting of drier years could determinate more or less abundance in dry years of the different well adapted body sizes (25). Finally, novel studies focused on genomic sequence and environmental change in non-model species like birds ${ }^{22-25}$ could provide future prospects to identify drought-resistant genes in individual small birds associated to terrestrial aquatic bodies in susceptible sectors as the semiarid landscapes.

\section{Acknowledgements}

I thank peers for the review of the first draft.

\section{Conflict of interest}

Author declares that there is no conflict of interest.

\section{References}

1. Iglesias A, Garrote L, Flores F, et al. Challenges to manage the risk of water scarcity and climate change in the Mediterranean. Water resources management. 2007;21(5):775-788.

2. Izah SC, Aigberua AO, Nduka JO. Factors affecting the population trend of biodiversity in the Niger Delta region of Nigeria. Int J Avian \& Wildlife Biol. 2018;3(3):199-207.

3. Zacchei D, Battisti C, Carpaneto GM. Contrasting effects of water stress on wetland-obligated birds in a semi-natural Mediterranean wetland. Lakes \& Reservoirs: Research \& Management. 2011;16:281-286.

4. Causarano F, Battisti C. Effect of seasonal water level decrease on a sensitive bird assemblage in a Mediterranean wetland. Rendiconti Lincei. 2009;20(3):211-218.

5. Grimm NB, Chapin FS, Bierwagen B, et al. The impacts of climate change on ecosystem structure and function. Frontiers in Ecology and the Environment. 2013;11(9):474-482.

6. Jiménez J, Hernández JM, Feliú J, et al. Breeding in a Dry Wetland. Demographic Response to Drought in the Common Reed-Warbler Acrocephalus scirpaceus. Ardeola: International Journal of Ornithology. 2018;65:247-259.
7. Peiró IG. The biodiversity of small passerine birds at wetlands: species loss and effects of climate change. Biodiversity Int J. 2018;2(3):297-301.

8. Peiró IG. Estudios ornitológicos basados en la gestión del hábitat de los Passeriformes del carrizal en el Parque Natural de El Hondo. PhD Thesis. Spain: University of Murcia; 2006.

9. Leisler B, Schulze-Hagen K. The reed warblers, Diversity in a uniform bird family. Zeist: KNNV Publishing; 2011.

10. Cramp S. The Birds of the Western Palearctic. Vol VI. Oxford: Oxford University Press; 1992.

11. Hinojosa-Huerta O, Nagler PL, Carrillo-Guererro YK, et al. Effects of drought on birds and riparian vegetation in the Colorado River Delta, Mexico. Ecological engineering. 2013;51:275-281.

12. Albright TP, Pidgeon AM, Rittenhouse CD, Claytonet al. Effects of drought on avian community structure. Global Change Biology. 2010;16(8):2158-2170.

13. George TL, Fowler AC, Knight RL, et al. Impacts of a severe drought on grassland birds in western North Dakota. Ecological Applications. 1992;2(3):275-284.

14. Blake JG, GE Niemi, JA Hanowski. Drought and annual variation in bird populations: Effects of migratory strategy and breeding habitat. In: J Hagan, M Johnston DW, editors. Ecology and conservation of Neotropical migrant landbirds. Washington: Smithsonian Institution Press; 1992:419-430.

15. Halidullin O. Man changed the function of water, and the water cycle changes the climate. Int J Avian \& Wildlife Biol. 2018;3(4):327.

16. Saetre GP, Post E, Král M. Can environmental fluctuation prevent competitive exclusion in sympatric flycatchers? Proceedings of the Royal Society of London B: Biological Sciences. 1999;266(1425):1247-1251.

17. Sturm M, Racine $C$, Tape $K$. Climate change: increasing shrub abundance in the Arctic. Nature. 2001;411:546.

18. Crick HQ. The impact of climate change on birds. Ibis. 2004;146(1):4856.

19. Bellard C, Bertelsmeier C, Leadley P, et al. Impacts of climate change on the future of biodiversity. Ecology letters. 2012;15:365-377.

20. Svensson L. Identification guide to European Passerines. Stockholm: L Svensson; 1992.

21. Nwaogu CJ, Tieleman BI, Cresswell W. Weak breeding seasonality of a songbird in a seasonally arid tropical environment arises from individual flexibility and strongly seasonal moult. Ibis. 2018.

22. Ellegren H. Genome sequencing and population genomics in non-model organisms. Trends in ecology \& evolution. 2014;29:51-63.

23. Hoffmann AA, Willi Y. Detecting genetic responses to environmental change. Nature Reviews Genetics. 2008;9:421.

24. Garroway CJ, Radersma R, Sepil I, et al. Fine-scale genetic structure in a wild bird population: the role of limited dispersal and environmentally based selection as causal factors. Evolution. 2013;67:3488-3500.

25. Nwaogu CJ, Tieleman BI, Bitrus K, et al. Temperature and aridity determine body size conformity to Bergmann's rule independent of latitudinal differences in a tropical environment. Journal of Ornithology. 2018;159:1053-1062. 